\title{
Sorting-Composting of Biodegradable Waste in the Municipality of Chief (Algeria): The Key Steps
}

\author{
Tahraoui Douma Naïmaa ${ }^{1,2^{*}}$, Matejka Guyb ${ }^{2}$ and Chambon Sergeb ${ }^{2}$ \\ ${ }^{1}$ Valorisation by composting of solid urban waste of the town Chlef, Algeria \\ ${ }^{2}$ Research Group for Water, Soil and Environment, University of Limoges, 16 rue Atlantis Parc ESTER Technopole 87068 Limoges, France
}

*Corresponding author: Tahraoui Douma Naïmaa, Research Group for Water, Soil and Environment, University of Limoges, 16 rue Atlantis Parc ESTER Technopole 87068 Limoges, France and laboratory: Water and Environment, University of Chlef, BP 151 Hay Essalam 02000 Chlef, Algeria, Tel: 09415695331 ; E-mail: naima.tahraoui@ensil.unilim.fr

Received date: November 23, 2015; Accepted date: March 03, 2016; Published date: March 09, 2016

Copyright: @ 2016 Naïmaa TD, et al. This is an open-access article distributed under the terms of the Creative Commons Attribution License, which permits unrestricted use, distribution, and reproduction in any medium, provided the original author and source are credited.

\begin{abstract}
In developing countries, sorting-composting of the urban solid residues (USR) requires the use of tools adaptable to the local conditions. To determine these optimal conditions of the process of sorting-composting of the biodegradable materials, an experiment was thrown at the level of the municipality of Chlef in Algeria. The parameters of follow-ups of the process of the fermentation were studied. The produced compost contain of the rates in $\mathrm{N}, \mathrm{P}, \mathrm{K}, \%$ in Carbon (\%C), \% in Organic matter (\%OM) and reports in $\mathrm{C} / \mathrm{N}$ acceptable by the standard NFU 44051 (the french standard of the organic amendments). The contents in elements metallic tracks $(\mathrm{Cd}, \mathrm{Cu}, \mathrm{Pb}, \mathrm{Ni}$ and $\mathrm{Zn}$ ) are lower than the limit standards. Also, the results of the analyses of the tests of phytotoxicity confirm that composts produced exhibit characteristics of organic amendments.
\end{abstract}

These results give birth to an important crossroads for the treatment of the part fermentable of the urban solid residues in Algeria and specifically to Chief.

Keywords: Municipal solid waste; Sorting-composting; Organic amendments

\section{Introduction}

The quantities of urban solid residues (USR) do not stop increasing with the economic and demographic development in the countries of the South, with for consequence the deposit of these residues in the unchecked discharges in conditions which do not answer necessarily at the necessary guarantees to avoid the atmospheric pollution, the contamination of ground waters, grounds and holiness of the environment.

As in all the countries of the South, the Algerian authorities (directions of the environment of the wilaya (department)) have to deal with this influx of waste by encouraging the sectors of valuation by composting and recycling of materials. In answer to these contrarieties of waste management, the implementation of a management system became the concern of the PROGDEM (National Program of Management of the municipal residues) since 2002; he built more than 80 technical landfills in almost all the Algerian cities.

But, this politics is not totally reassuring because the saturation of landfills is reached quickly because of the big quantities of waste generated by the population, he a results from it the risks of environmental pollution because of the bad masters of the techniques of recoveries of biogases and the big volumes of the leachate generated by the presence of big rate of organic matter (more than $70 \%$ ) in the composition of SUR. The integration of the organic valuation can reduce significantly the problems of pollution and will contribute to an adequate management of waste. Because, the composting is more and more considered as an ecologically long-lasting component [1] in a management system integrated of the waste, what is going to limit the production of the methane [2] and leachates [3]. The composting also allows an improvement of the fertilizing value by reduction of the masses and the volumes of the initial waste $[4,5]$. The composting limits the production the methane [2] and leachate [3]. It also allows, improved fertilizer value, and a reduction in masses and volumes of the wastes [4,5]. The produced compost contain of the fertilizing elements, $\mathrm{N}, \mathrm{P}$ and $\mathrm{K}[6]$ and trace elements (Mg, Iron, $\mathrm{Ca}$, etc.), so allowing, the nutrition of plants, what will increase the yields of the cultures [6,7].

The results of the physical characterization of the solid household waste of the municipality of Chlef during three years and various seasons (Table 1) show that the fermentable (putrescible, paperscardboards, CNC) prevail. Therefore, the composting is an adequate solution of waste treatment in parallel to the technical burying.

In the light of these results, the objective of this experiment is to determine the most adapted conditions of composting, that is to say, the type of substratum, the frequency of the flipping, the durations of fermentation and maturation and the effect of the recirculation of the refusals on the line of production of the compost. For that purpose, various parameters were followed such as: the temperature, the $\mathrm{pH}$, the content in organic matter, the humidity and the size grading of the substrata. Also, the composition of the produced compost obtained was followed in terms of the rate in fertilizing elements and in metal trace elements, and also the phytotoxicity.

\begin{tabular}{|l|l|l|l|l|l|}
\hline Zones & East & West & $\begin{array}{l}\text { City } \\
\text { Centre }\end{array}$ & South & North \\
\hline Categories & \multicolumn{5}{|c|}{$\%$} \\
\hline Putrescible & $56.8-74.6$ & $53.6-77.2$ & $53.2-73.2$ & $\begin{array}{l}61.2-74 . \\
3\end{array}$ & $54.3-74.3$ \\
\hline
\end{tabular}


Citation: Naïmaa T, Guyb M, Sergeb C (2016) Sorting-Composting of Biodegradable Waste in the Municipality of Chief (Algeria): The Key Steps. Int J Waste Resour 6: 204. doi:10.4172/2252-5211.1000204

Page 2 of 11

\begin{tabular}{|c|c|c|c|c|c|}
\hline Papers & $1.7-3.7$ & $1.2-5.8$ & $2.1-5$ & $1.3-4.9$ & $1.2-3.3$ \\
\hline Cardboard & $1.9-8.1$ & 3.3-7.4 & $2.5-7.2$ & $2.0-5.6$ & $3.7-7.1$ \\
\hline Composites & $1.5-2.7$ & $0.9-2.9$ & $1.6-3.3$ & $1.1-3.8$ & $1.2-2.2$ \\
\hline Textiles & $1.3-3.2$ & $1.6-3.2$ & $1.3-5.3$ & $1.0-2.5$ & $1.4-2.6$ \\
\hline $\begin{array}{l}\text { Sanitary } \\
\text { textiles }\end{array}$ & $4.4-11$ & $4.8-9.8$ & $3.8-14.8$ & $5.2-11.0$ & $5.5-14.1$ \\
\hline Plastics & $5.8-10.8$ & $6.1-11.2$ & $7.8-11.3$ & $4.2-10.3$ & $6.6-9.7$ \\
\hline $\begin{array}{l}\text { Combustible } \\
\text { s Not } \\
\text { Classified } \\
\text { (CNC) }\end{array}$ & $0.2-0.9$ & $0.1-0.5$ & $0.3-1.3$ & $0.3-0.8$ & $0.9-1.4$ \\
\hline Glass & $0.7-3.9$ & $0.5-1.1$ & $0.7-5.2$ & $1.2-1.9$ & $1.0-3.3$ \\
\hline Metals & $0.6-2.0$ & $0.6-1.7$ & $0.7-2.9$ & $0.9-2.5$ & $0.7-2.6$ \\
\hline $\begin{array}{l}\text { Incombustibl } \\
\text { es Not } \\
\text { Classified } \\
\text { (INC) }\end{array}$ & $0.2-0.7$ & $0.5-1.9$ & $1.0-2.0$ & $0.8-1.5$ & $1.4-3.4$ \\
\hline $\begin{array}{l}\text { Hazardous } \\
\text { wastes }\end{array}$ & $0.4-3.1$ & $0.5-1.3$ & $0.5-0.7$ & $0.6-1.0$ & $0.6-1.0$ \\
\hline $\begin{array}{l}\text { Fines } \quad(<.20 \\
\mathrm{mm})\end{array}$ & $0.5-1.9$ & $0.4-2.3$ & $0.8-8.2$ & $0.5-2.0$ & $0.6-10.2$ \\
\hline
\end{tabular}

Table 1: MSW composition of the five zones of the municipality of Chlef (Years: 2010-2011; 2011-2012 and 2012- 2013).

\section{Materials and Methods}

\section{The experimental platform of sorting-composting of the MSW}

The area of platform includes two parts:

- A covered area of $100 \mathrm{~m}^{2}$ intended of at waste sorting, at sieving, as well at storage of compost.

- The second surface is $100 \mathrm{~m}^{2}$ divided into two parts: each part has a length of $10 \mathrm{~m}$ and a width of $5 \mathrm{~m}$, separated by a channel. Each surface is inclined by $2 \%$ allowing the flow of leachate and the drainage rain water. The leachate is directed through the channel to a recovery basin. On each area, two tons of fermentable are composted (Figure 1). The surface of composting is not covered.
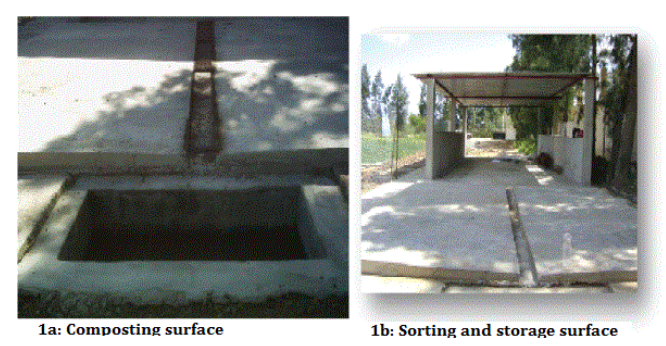

Figure 1: Composting pilot platform.

The material available in the platform:

For the physical characterization of waste:

- A waste sorting table according MODECOM standards (method of characterization of household waste).

- Two electronic scales with a capacity of $5 \mathrm{~kg}$ and $130 \mathrm{~kg}$.

To follow up the fermentation of waste and physical characterization compost product:

- A probe in order to follow the variation of temperature into the windrows.

- The sieves of $20 \mathrm{~mm}$ and of $100 \mathrm{~mm}$ to determine the distribution in size of the substrates during composting, and sieves of $10 \mathrm{~mm}$ and of $40 \mathrm{~mm}$ for the sifting final produced compost.

Finally: - Shovels, forks, bags, gloves, masks and boots.

\section{Experimental conditions of composting}

Following the bibliographical study, the choice being technically inclined at the aerated windrows by successive turning, and the eventual water inflows, it is essential to study the different composting conditions mainly:

- Nature of the substrate: raw waste or pre-sorted.

- Frequency of flipping.

- Recirculation of the refusal.

- Sifting the product compost by different sizes: Compost $\leq 40 \mathrm{~mm}$ and compost $\leq 10 \mathrm{~mm}$.

According to these assumptions, the stages of the experimental approach are the followings:

Step 1: Preparation of the substrate: the sorting of certain categories.

Step 2: construction of windrows.

Step 3: fermentation with aeration. Two frequencies are selected: aeration by day $\left(2^{\text {nd }}, 4^{\text {th }}, 8^{\text {th }}, 15^{\text {th }}\right.$ and $30^{\text {th }}$ day) or the aeration by week $\left(1^{\text {st }}, 2^{\text {nd }}, 3^{\text {rd }}, 4^{\text {th }}, 7^{\text {th }}, 9^{\text {th }}\right.$ and $11^{\text {th }}$ week $)$. Watering is applied during the degradation phase in order to maintain the windrow moisture between $40 \%$ and $60 \%$.

Step 4: maturation during 3 months.

Step 5: final refining by sieving.

\section{Windrows form and size}

In this study, the trapezoidal shape is maintained for the various windrows. The composting experience was spread over two years during different seasons (winter, spring and summer). The dimensions and the masses of the various heaps are reported in Table 2. 


\begin{tabular}{|c|c|c|c|c|c|c|}
\hline \multirow{2}{*}{ Windrows } & \multirow[b]{2}{*}{ Season } & \multirow[b]{2}{*}{ Mass $(\mathrm{Kg})$} & \multicolumn{4}{|c|}{ Dimensions (m) } \\
\hline & & & First base & Second base & Height & Length \\
\hline$W_{1}$ & Spring & 1352 & 1.5 & 0.5 & 1.35 & 7 \\
\hline$W_{2}$ & Summer & 2000 & 2.5 & 1 & 2 & 9 \\
\hline$W_{3}$ & Winter & 1200 & 1.5 & 0.5 & 1.2 & 7 \\
\hline$W_{4}$ & Spring & 1500 & 1.5 & 0.5 & 1.4 & 8 \\
\hline
\end{tabular}

Table 2: Size and mass of experimental windrows.

The different stages of the composting process are developed by the following schema (Figure 2):

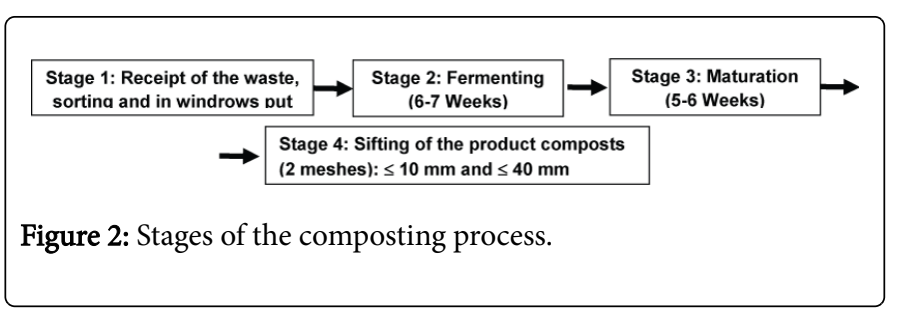

\section{Parameters followed of the composting}

The following parameters of the composting process were analyzed as follows: probe;

- Exothermic Effect $\left(\mathrm{T}^{\circ} \mathrm{C}\right)$ : The temperature was measured by a

- Acidity $(\mathrm{pH})$ : The $\mathrm{p}^{\mathrm{H}}$ was measured using a combined glass electrode and a $\mathrm{pH}$ meter;

- Water content $(\% \mathrm{H})$ : The moisture was determined by drying a mass of $100 \mathrm{~g} \pm 0.1 \mathrm{~g}$ in an oven at $105{ }^{\circ} \mathrm{C}$ for 24 hours (AFNOR standard NF U 44-171 October 1982).

- Organic matter content (\%OM/DM): The organic matter content relative to the dry matter $(\mathrm{DM})$ was determined by the loss on ignition by mass during calcining of a sample at $550^{\circ} \mathrm{C}$ for two hours after drying [8]. The rate of the OM was determined during the composting process, and for each produced compost ( $\leq 10 \mathrm{~mm}$ and $\leq 40 \mathrm{~mm}$ ).

\section{Analysis of the compost}

For this analysis several methods are used:

- Carbon content (in mg C/g or \%C /DM): According to the works of Giroux and Audesse [9], the carbon content is evaluated according to the following equation (1).

$\% \mathrm{OM}=\% \mathrm{C} \times 2,0 \ldots$

- Nitrogen content (NTK), mg/g or \%N/DM was determined by the Kjeldahl method [10].

- The rates of elements fertilizer and the rates metals are determined by Atomic Adsorption Spectroscopy after mineralization [2,11-14].

- The phosphorus content: the total phosphorus was determined by a specific spectroscopic automated analyzer after mineralization.

\section{Maturation test}

The maturation of the produced compost is controlled by the Germination Index (GI) [15].

Principle: the cress seeds (Lepidium sativum) and lettuce seeds are placed in a series of petri dishes with filter paper. The filter paper is soaked with increasing doses of distilled water (DW) and the compost extract (CE). Doses are: (100\% DW; $75 \%$ DW + 25\% EC; $50 \%$ DW + $50 \%$ EC; $25 \% \mathrm{DW}+75 \% \mathrm{EC}$; EC $100 \%)$. The assembly is placed in a germination chamber (incubator) at $27^{\circ} \mathrm{C}$ for 24 hours. At the end of the germination, the numbers of germinated seeds were enumerated and the lengths of the roots were measured.

The germination index (GI) is calculated by the following equation (2).

$$
\mathbf{G I}=\left(\frac{\mathbf{G B}}{\mathbf{G T}}\right) \times\left(\frac{\mathbf{L B}}{\mathbf{L T}}\right) \times \mathbf{1 0 0}
$$

With,

GI: germination index (\%). GB: number of germinated seeds of the intakes of compost.

GT: number of germinated seeds of the witness treatment.

LB: root length of compost inflows.

LT: root length of the witness treatment.

\section{Results and Discussions}

The most suitable composting conditions are shown in Table 3, that is to say the type of substrate to be composted, the turning frequency, water yield, the minimum duration of fermentation and maturation. As well as, the effect of the recirculation of refusal on the compost production line. For that, various parameters were monitored during the composting as, the temperature, humidity $(\% \mathrm{H}), \mathrm{pH}$, organic matter $(\% \mathrm{OM})$ and the particle sizes of the substrate.

- The substrates in the windrows are constituted by a mixture of wastes after sorting the undesirables (metals, glass, sanitary plastics and hazardous the waste). The waste comes from the five areas of the city Chlef.

- The windrows aeration is important, especially during the first weeks of composting (mesophilic phases, thermophilic and cooling). Two different frequencies of flipping were selected and tested during these experiments.

\begin{tabular}{|l|l|l|l|}
\hline $\begin{array}{l}\text { Windrow } \\
\mathbf{S}\end{array}$ & Period & $\begin{array}{l}\text { Substrates } \\
\text { composition }\end{array}$ & Flipping \\
\hline
\end{tabular}




\begin{tabular}{|c|c|c|c|}
\hline$W_{1}$ & Spring 2011 & $\begin{array}{l}\text {-Putrescible: } 57.7 \% \\
\text {-Papers: } 15 \% \\
\text {-Cardboard: } 20.7 \% \\
\text {-Fines (<20mm): } 6,6 \%\end{array}$ & $\begin{array}{l}\text { F1: 2th D; 4th D; 8th D; } \\
\text { 15th D; 30th D. }\end{array}$ \\
\hline W2 & $\begin{array}{l}\text { Summer } \\
2011\end{array}$ & $\begin{array}{l}\text {-Putrescible: } 72 \% \\
\text {-Cardboard: } 4.5 \% \\
\text {-Papers: } 4 \% \\
\text {-Plastics } \quad(20-100 \quad \mathrm{~mm}): \\
10 \% \\
\text {-CNC:1.5\% } \\
\text {-Fines (<20 mm): } 8 \%\end{array}$ & $\begin{array}{l}\text { F2: 2th D; 4th D; 8th D; } \\
\text { 15th D; 30th D. }\end{array}$ \\
\hline$W_{3}$ & Winter 2012 & $\begin{array}{l}\text {-Putrescible: } 66.5 \% \\
\text {-Papers: } 4.2 \% \\
\text {-Cardboard: } 3.3 \% \\
\text {-Plastics } \quad(20-100 \quad \mathrm{~mm}) \text { : } \\
8 \% \\
\text {-CNC: } 2.8 \% \\
\text {-Fines }(<20 \mathrm{~mm}): 10.2 \%\end{array}$ & $\begin{array}{l}\text { F3: 1th W; 2th W; 3th W; } \\
\text { 4th W; 7th W; 9th W; 11th } \\
\text { W. }\end{array}$ \\
\hline W4 & Spring 2012 & $\begin{array}{l}\text {-Putrefiable:54\% } \\
\text {-Cardboard:6\% } \\
\text {-Papers:5\% } \\
\text {-Plastics }(20-100 \quad \mathrm{~mm}) \text { : } \\
\text { 8\%; }\end{array}$ & $\begin{array}{l}\text { F4: 1th W; 2th W; 3th W; } \\
\text { 4th W; 7th W; 9th W; 11th } \\
\text { W. }\end{array}$ \\
\hline
\end{tabular}

\begin{tabular}{|c|c|c|}
\hline & & 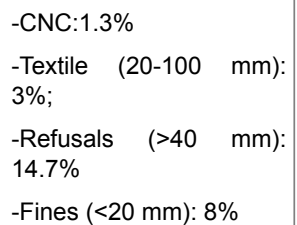 \\
\hline
\end{tabular}

Table 3: Various composting conditions studied. Note: D: Day; W: Week; F: Flipping.

\section{Influence of the flipping frequency of the windrows on the different parameters $\left(\mathrm{T}^{\circ} \mathrm{C}, \mathrm{pH}, \mathrm{OM}, \mathrm{H}\right.$ and particle size)}

For this goal we compare the evolution of the windrows $2\left(\mathrm{~W}_{2}\right)$ and $3\left(\mathrm{~W}_{3}\right)$, composed by of the identical categories of substrate. The frequencies of the flipping are different.

\section{Evolution of the temperature and humidity}

The evolution of temperature in $\mathrm{W}_{2}$ (Figure $3 \mathrm{a}$ ) shows that the composting has already reached the thermophilic phase $\left(\mathrm{T}^{\circ} \mathrm{C}=75^{\circ} \mathrm{C}\right)$ very quickly in the first hours certainly because the composting process has begun before the windrow construction. For W3, the fermentation takes place in three phases: phase mesophilic and phase thermophilic where the temperature reaches a maximum of $65^{\circ} \mathrm{C}$, and a phase of deceleration (stabilization). The process of the windrow 3 is similar to that described by Kaiser [16].

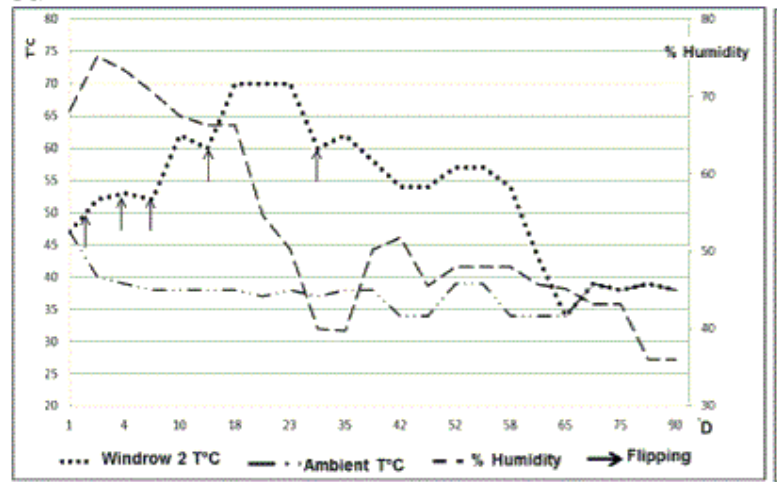

3a: $\mathbf{W}_{2}$

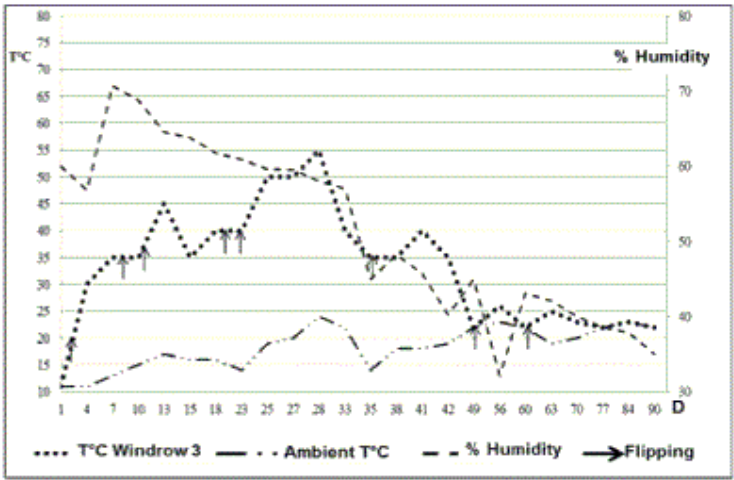

3b: $\mathbf{W} 3$

Figure 3: Evolution of the temperature and humidity during the composting $\mathrm{W}_{2}$ and $\mathrm{W}_{3}$.

The humidity at the beginning of composting is in the order of $66 \%$ within $\mathrm{W}_{2}$ and $52 \%$ within $\mathrm{W}_{3}$, of the ideal values for a start of fermentation $[17,5]$. These values are due to the presence of $72 \%$ of putrescible in $\mathrm{W}_{2}$ and $66.5 \%$ of putrescible in $\mathrm{W}_{3}$.

The water content decreases when the temperature increases or if the upturns are close together and mostly during the fermentation phase. These decreases are synonymous with loss of water in vapor form Mustin [18]. Moisture is maintained during the fermentation between $50 \%$ and $60 \%$ per watering of swaths. The increase in humidity is due and to the season and to the surface of composting which is not covered.

\section{Evolution of the $\mathrm{pH}$}

The evolution of $\mathrm{pH}$ does not correspond to the theoretical evolution during composting. Indeed, we did not the acidification phase at the beginning of the process, this is proof that biodegradation has started before the constitution of the windrow.

The slight acidity at the beginning of the composting is linked to the formation of organic acids during the decomposition of organic substrates and volatilization of the ammonia. This phenomenon was confirmed by Mustin [18], the initial ammonification is due of the degradation of organic acids. Thereafter, $\mathrm{pH}$ increases is caused by the disappearance of the easily degradable organic matter and at his mineralization [19] (Figure 4). 


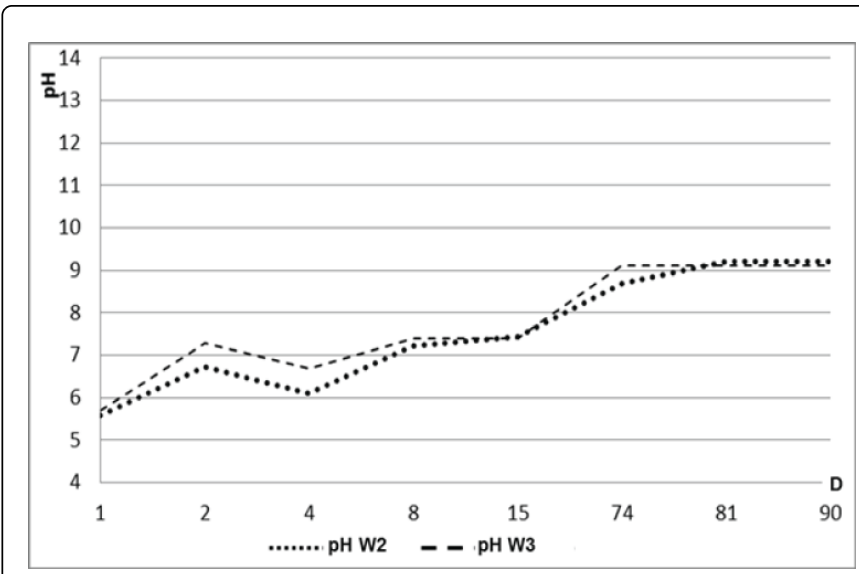

Figure 4: Evolution of the $\mathrm{pH}$ during the composting $\mathrm{W}_{2}$ and $\mathrm{W}_{3}$.

\section{Evolution of organic matter (\%OM) and particule size}

The content of organic matter $(\mathrm{OM})$ in $\mathrm{W}_{2}$ decreases during the composting process, from 58\% / DM (dry matter) up to $36 \% / \mathrm{DM}$ (Figure 5). For $\mathrm{W}_{3}$, the $\% \mathrm{OM}$ varies from $58 \% / \mathrm{DM}$ to $28 \% / \mathrm{DM}$.

The results show that during the first two weeks of composting, the percentage of the organic matter of the both windrows varies in the same direction, although the starting substrates are not the same. This is due to the degradation of putrescible, paper, cardboard and the fine material. The presence of plastics and textiles in $\mathrm{W}_{3}$ has no influence on the evolution of the OM content. This decrease is related to the mineralization of organic matter by microorganisms [20-22].

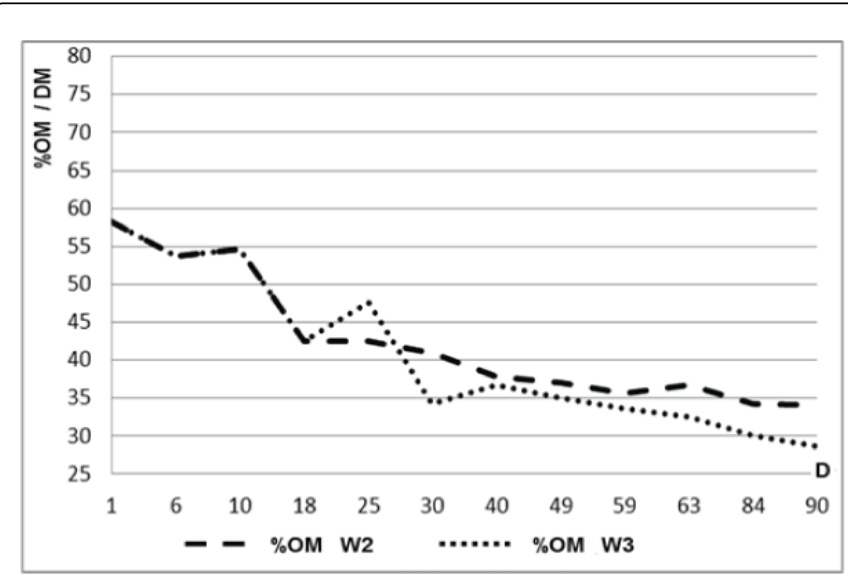

Figure 5: Evolution of the $\mathrm{OM}$ during the composting $\mathrm{W}_{2}$ and $\mathrm{W}_{3}$.

The particle size is a parameter which determines the progressive destruction rate of substrates during composting. Figure 6 shows a decrease in particle size $>10 \mathrm{~cm}$ and $>5 \mathrm{~cm}$, and an increase of percentages of the particle size $<1 \mathrm{~cm}$ in both windrows. This increase is the result of the degradation of the substrates during the composting process.

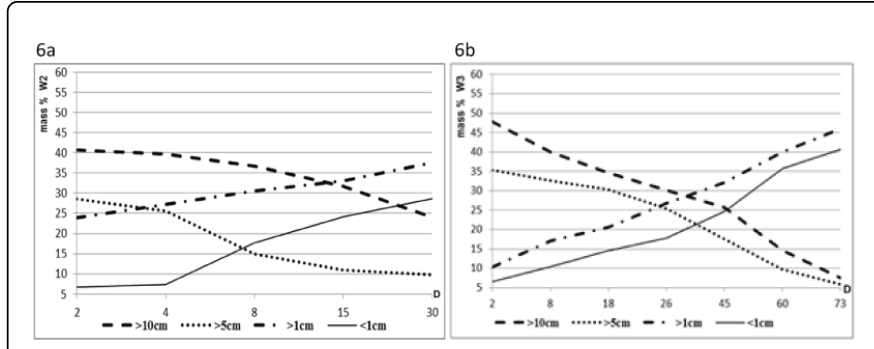

Figure 6: Evolution of the granulometry during the composting $\mathrm{W}_{2}$ and $\mathrm{W}_{3}$.

At the beginning of composting, the percentage of particles of size > $10 \mathrm{~cm}$ of the windrow 2 is $41 \%$, at the end of the composting, the rate is $25 \%$. To $\mathrm{W}_{3}$, the rate of the particle of size $>10 \mathrm{~cm}$ is from $47 \%$. And at the end of the process, the rate of the particles of size $>10 \mathrm{~cm}$ decrease to $8 \%$.

Material degradation continues until the third phase of composting. These changes in percentages of particles of different sizes vary with the nature of the substrates, aeration and microbial activity in each windrow [5].

Aeration at the beginning of fermentation is recommended, especially in the case of the presence of the unclassified combustibles, and also in the case of the reintroduction of refusal to the head of a composting. In conclusion, the upturns the most suited are: $2^{\text {nd }}$ day, $4^{\text {th }}$ day, $8^{\text {th }}$ day, $13^{\text {th }}$ day, $15^{\text {th }}$ day, seventh week, eleventh week and fifteenth week. These frequencies are ideal during a composting process of municipal solid waste. According to these results, the frequencies of the flipping directly influence the parameters of the composting process.

\section{Influence of the nature of the substrate of the windrows on the different parameters $\left(\mathrm{T}^{\circ} \mathrm{C}, \mathrm{pH}, \mathrm{OM}, \mathrm{H}\right.$ and particle size)}

The choice of substrates destined for the composting determines the quality of the resulting compost. This study presents the evolution of the following parameters: temperature, humidity, $\mathrm{pH}, \mathrm{MO}$, particle size.

\section{Evolution of the parameters, temperature $\mathrm{T}^{\circ}$ and humidity $\mathrm{H}$ $\%$}

In $\mathrm{W}_{2}$, the thermophilic microorganisms are in full activity from the first week. The temperature increases to a maximum of $70^{\circ} \mathrm{C}$ during the third week. In $\mathrm{W}_{1}$, it attains $60^{\circ} \mathrm{C}$ within the first week and after two flipping, the temperature is again $60^{\circ} \mathrm{C}$ during the third week.

The difference of the two maximum temperatures in the two windrows is the results, on the one hand of the difference in ambient temperatures (summer and spring), and secondly, of the difference of the substrates in the two heaps. The temperature in the windrow 2 remains constant $\left(70^{\circ} \mathrm{C}\right)$ for three days. This finding is due to the presence of plastic materials that retain heat.

During this phase the microorganisms degrade the materials carbonaceous degradable. This results the $\mathrm{CO}_{2}$ release and the $\mathrm{H}_{2} \mathrm{O}$ training. This step is followed by a slow phase (cooling phase), which begins from the $7^{\text {th }}$ week in the $\mathrm{W}_{1}$, and from the $9^{\text {th }}$ week in the $\mathrm{W}_{2}$. 
In this mesophilic phase, others microorganisms destroy the woody materials [4].

In the $\mathrm{W}_{2}$, the composting process is slower than in the W1. This difference is probably due to differences between substrates initials of both windrows (Figure 7).

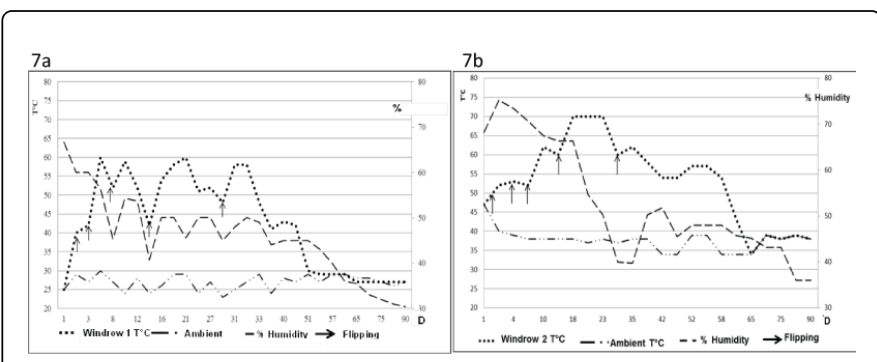

Figure 7: Evolution of the temperature and humidity during the composting $\mathrm{W}_{1}$ and $\mathrm{W}_{2}$.

The decrease of the humidity probably is the result high temperatures during the process, and also of differences of the substrates and aeration of the two swaths. According Godden [23], a humidity $<40 \% / \mathrm{BM}$ (Brute Matter) results a slowdown of the microbial activity. Moisture is thus related to the aeration and she essentially depends on the nature of materials destined for the composting [23].

\section{Evolution of the $\mathrm{pH}$}

At the beginning of the composting process, the followed of the $\mathrm{pH}$ showed that in the two windrows, the $\mathrm{pH}$ is slightly acidic, it to a value of the order of 5.5 (Figure 8). At the end of the processes, the $\mathrm{pH}$ increases to reach a value of 9 for both composts.

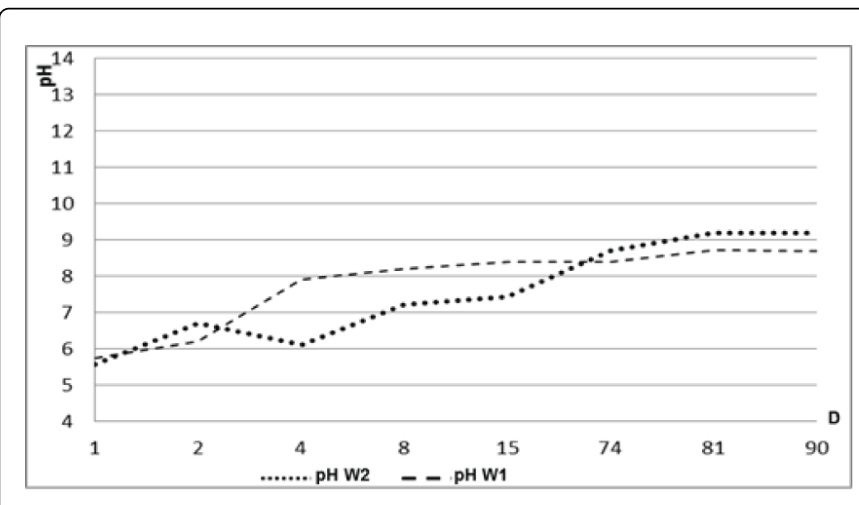

Figure 8: Evolution of the $\mathrm{pH}$ during the composting $\mathrm{W}_{1}$ and $\mathrm{W}_{2}$.

\section{Evolution of the organic matter and the granulometry}

Generally the evolution of the OM in the composting goes through a phase of maturation and a stabilization step. According to Figure 9, it is noted that the organic material is high at the beginning of the process and then, it decreases to stabilize at the end of the composting.

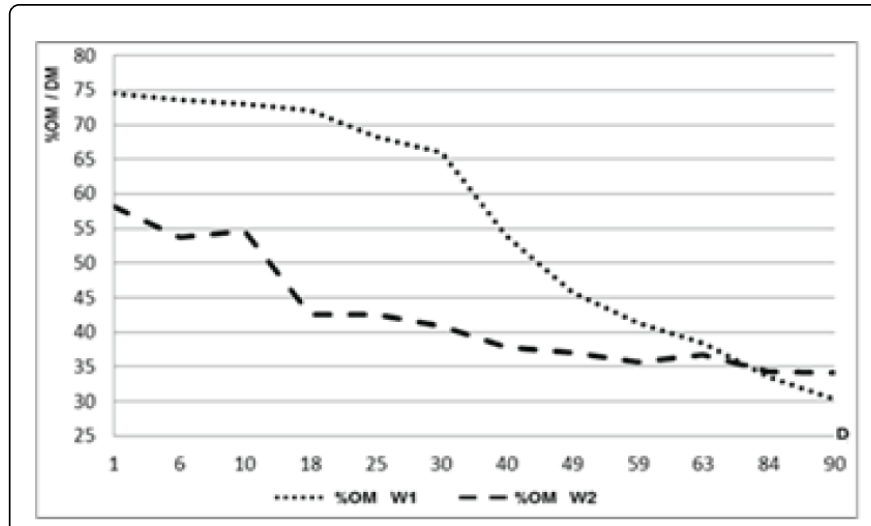

Figure 9: Evolution of the $\mathrm{OM}$ during the composting $\mathrm{W}_{1}$ and $\mathrm{W}_{2}$.

The measurement results of them particle of the windrow 1 and of the windrow 2 , are schematically represented as follows (Figure 10).

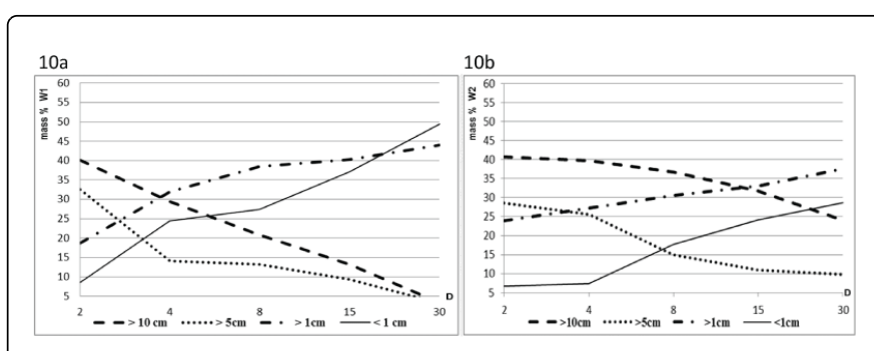

Figure 10: Evolution of the granulometry during the composting $\mathrm{W}_{1}$ and $\mathrm{W}_{2}$.

The no classified combustibles are often used as structuring elements favoring the aeration although their degradation is slow during composting. At the end of the composting, the results show that the percentages of the size fraction $<1 \mathrm{~cm}$ are respectively $50 \%$ and $28.7 \%$. These results are consistent with the mixture of starting: $\mathrm{W}_{1}$ contains $100 \%$ biodegradable materials and $\mathrm{W}_{2}$ contains only $80 \%$.

In $\mathrm{W}_{2}$, the temperature increases from the first week to because of the presence of the plastics and textiles present in the latter. By cons in the windrow 1 , the temperature normally evolves. Water inflows are limited in $\mathrm{W}_{1}$, but in $\mathrm{W}_{2}$, the water inflows from addition starting from the fourth week. This is explained by the difference in the two substrates in the two windrows. The particles $<1 \mathrm{~cm}$ increases in the windrow 1 , much more than in $\mathrm{W}_{2}$, this is due to the presence of plastics and textiles in the windrow 2.

The nature of the starting materials is very important for to ensure a smooth composting. According to this study, the nature and composition of substrates directly influence the composting tracking parameters and on the quality of the compost. Therefore, the choice of substrates is very important.

\section{Influence of the recirculation of the sieving refuse of the windrows on the different parameters $\left(\mathrm{T}^{\circ} \mathrm{C}, \mathrm{pH}, \mathrm{OM}, \mathrm{H}\right.$ and particle size)}

Does the reintroduction of the refusals in the composting influences the parameters during the process? To answer this question, the 
refusals of the windrow 3 have been reincorporated with the materials from $\mathrm{W}_{4}$.

\section{Evolution of the temperature and of the humidity}

Figures 11a and $11 \mathrm{~b}$ illustrate the evolution of the temperature and humidity during composting the windrow 3 and $\mathrm{W}_{4}$. The maximum temperature in $\mathrm{W}_{3}$ is $55^{\circ} \mathrm{C}$ after the fifth turning. The maximum temperature of the windrow 4 reached $70^{\circ} \mathrm{C}$ during the first week after the second flipping. The rapid increase of temperature in $\mathrm{W}_{4}$ is the result of, one hand, of the presence of the microorganisms in the refusals (seeding of the heap), on the other hand, a self-sterilization of the material with the neutralization of pathogens and of seeds adventives [5,24].

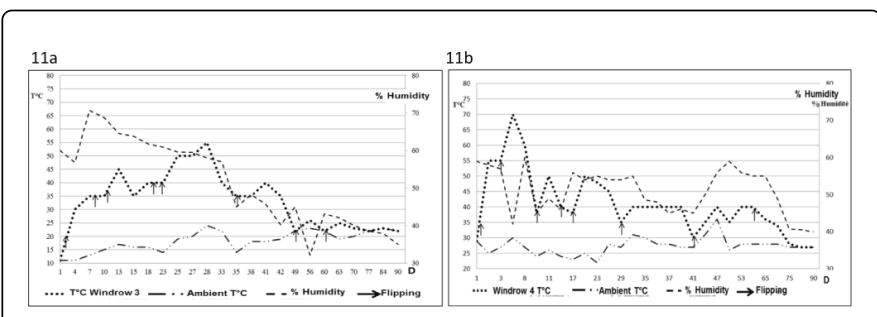

Figure 11: Evolution of the temperature and humidity during the composting $\mathrm{W}_{3}$ and $\mathrm{W}_{4}$.

According Mustin [5], the water that is in the organic particles (solid fraction) and in the lacunar spaces (water vapor) is metabolic water produced by the microorganisms. At the beginning of composting processes, the water content is $60 \%$ in the windrow 3 and of $64 \%$ in the windrow 4 . She reaches $70 \%$ in the windrow 3 and $75 \%$ in the windrow 4.

In the windrow 4 , the rapidly dwindling of the humidity during the first week of fermentation is the result from the rise the temperature $\left(70^{\circ} \mathrm{C}\right)$ and of the upturning. According to Mustin [5], moisture tends to decrease under the conjugate action of the temperature increase and from the upturning, which resulting in losses of water in form of water vapor. The humidity is adjusted by watering.

The aeration frequencies are essential during the first 5 weeks of composting for to bring from the oxygen, cool the heap, increase the lacunar spaces to facilitate the circulation of air within the swath and homogenize the substrate $[5,17,25]$.

\section{Evolution of the $\mathrm{pH}$}

The $\mathrm{pH}$ of the windrow 3 increased by 5.7 to 7 during the first week, and then slightly during the week second of composting to for reach 7.6. This value remained almost constant until the seventh week. At the end of the process the $\mathrm{pH}$ reach 9 (Figure 12). Apparently, this increase indicates an alkalizing phase (dominant thermophilic flora) with fatty acid degradation and ammonia production following the breakdown of organic acids [18]. The high value of the $\mathrm{pH}$ at the end of the composting is due to ammonium oxidation by the bacteria and precipitation of calcium carbonate $\left(\mathrm{CaCO}_{3}\right)$.

The $\mathrm{pH}$ in $\mathrm{W}_{4}$ decreases at the beginning of the thermophilic phase for 6.5 to 6 , then increases gradually. At the end of the composting, the $\mathrm{pH}$ the value reached 9. The addition of the refusals in the heap 4 is probably the cause of the short phase of the acidogénèse (production of the $\mathrm{CO}_{2}$ and organic acids). Starting from the 9th week, the $\mathrm{pH}$ remains constant. This can be explained by stopping the activity of micro-organisms responsible for the change in the $\mathrm{pH}$.

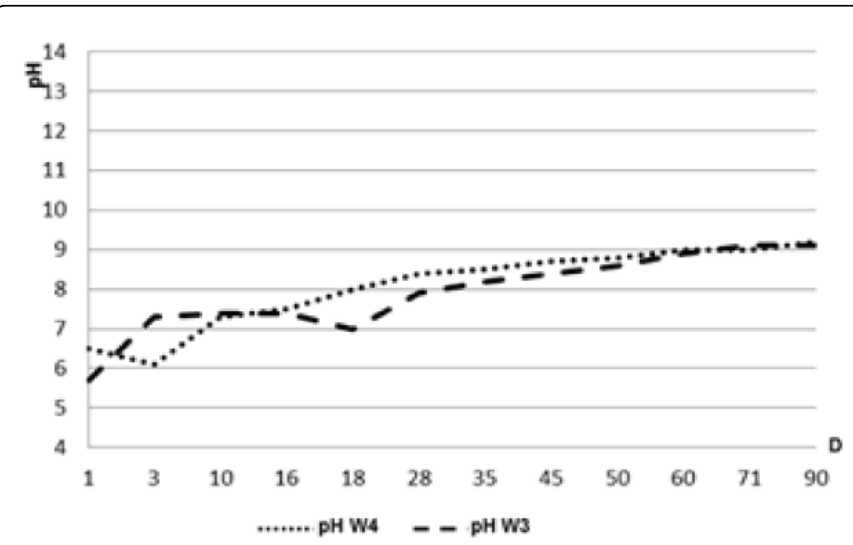

Figure 12: Evolution of the $\mathrm{pH}$ during the composting $\mathrm{W}_{3}$ and $\mathrm{W}_{4}$.

\section{Evolution of the organic matter and the granulometry}

At the end of the composting, the rate of the organic matter of the two composts is by $50 \%$ compared to that of raw wastes. The loss of organic matter of fermentable waste is over 50\% [24,25]. According Mustin [5], the average loss of organic matter varies between 35 and $50 \%$ for a $\mathrm{C} / \mathrm{N}$ optimal at the beginning of fermentation.

The difference in content of initial organic matter is related to the percentages of substrates in each windrow (Figure 13). The measurements carried out show rapid degradation of the organic material during the mesophilic phase into the two swaths. These results confirm the influence of the difference of the initial substrates. However, regardless of the difference of the substrates, the degradation of the organic material is accompanied by a loss of carbon as carbon dioxide and volatile compounds.

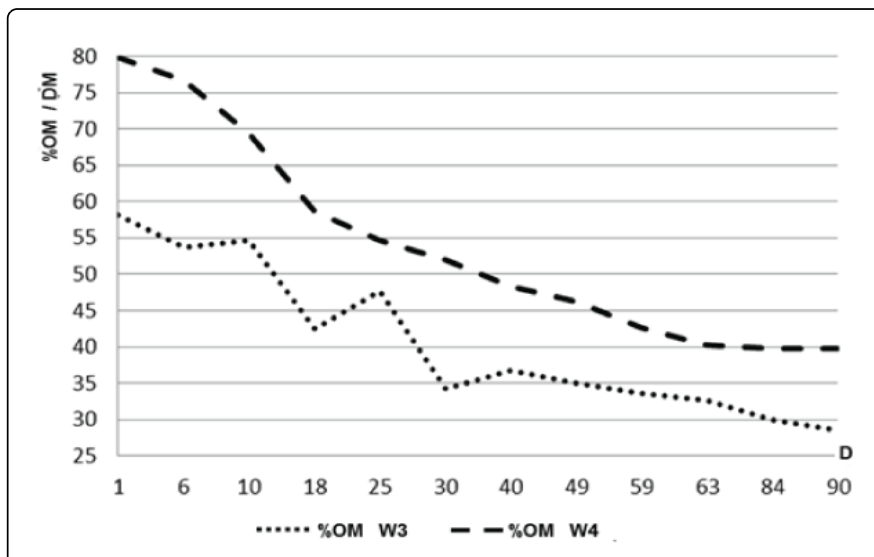

Figure 13: Evolution of the OM during the composting $\mathrm{W}_{3}$ and $\mathrm{W}_{4}$.

If the particles are infinitely little (less than $5 \mathrm{~cm}$ ), the space is reduced which blocks the flow of air into the heap during composting [26]. In reality, more a material is divided, the more the degradation speed is fast [5].

The rapid degradation of substrates leads to increased rate of microbial activity [5]. The measurements show that the particles size 
Page 8 of 11

percentage $>10 \mathrm{~cm}$, and the percentage particles size $>5 \mathrm{~cm}$ are respectively $47 \%$ and $35 \%$ in W3. But, those of the heap 4 are from $40 \%$ and $38 \%$ (Figure $14 \mathrm{a}$ and $14 \mathrm{~b}$ ). At the end of the process, the rates of these particles decrease and the percentage of particle size $<1 \mathrm{~cm}$ increases to reach $40 \%$ in the windrow 3 , and $50 \%$ in the heap 4 . These results show that the contact surface is more significant in the windrow 4 relative to the windrow 3 . The uploading of the residues into the windrow 4 increases the amount of structuring materials.

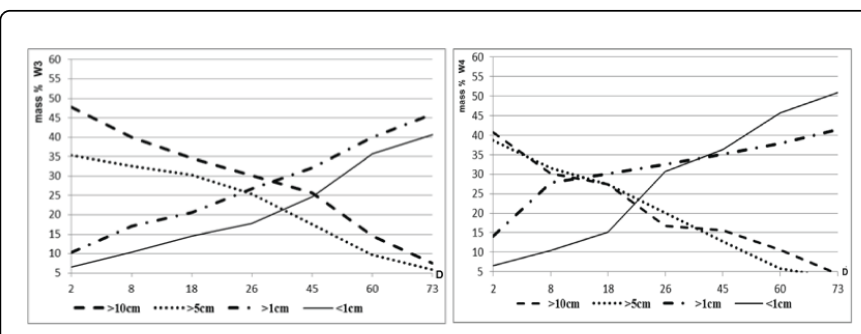

Figure 14: Evolution of the granulometry during the composting $\mathrm{W}_{3}$ and $\mathrm{W}_{4}$.

\section{Conclusion}

The temperature increases from the first week in $\mathrm{W}_{4}$, which is explained by the addition of refusal (bacterial seeding). This results in a normal evolution in the $\mathrm{pH}$ in the windrow 4 . Also, the introduction of refusal at the head of the process entails a lot of water inflows from the first week of the process. This is reflected in a significant degradation of the particles and a significant increase in fine $<1 \mathrm{~cm}^{\text {in }} \mathrm{W}_{4}$.

\section{Influence of conditions on the compost produced}

The sifting of the composts was carried out using square-mesh sieves of $40 \mathrm{~mm}$ and $10 \mathrm{~mm}$. The symbols of sifting are listed in Table 4.

\begin{tabular}{|l|l|l|l|}
\hline \multicolumn{2}{|l|}{ Sifting of the compost } & $\mathbf{\leq 1 0} \mathbf{~ m m}$ & $\mathbf{1} \mathbf{4 0} \mathbf{m m}$ \\
\hline Compost 1 (C1) & Spring 2011 & $\mathrm{C} 1 / 10$ & $\mathrm{C} 1 / 40$ \\
\hline Compost 2 (C2) & Summer 2011 & $\mathrm{C} 2 / 10$ & $\mathrm{C} 2 / 40$ \\
\hline Compost 3 (C3) & Winter2012 & $\mathrm{C} 3 / 10$ & $\mathrm{C} 3 / 40$ \\
\hline Compost 4 (C4) & Spring 2012 & $\mathrm{C} 4 / 10$ & $\mathrm{C} 4 / 40$ \\
\hline
\end{tabular}

Table 4: Symbols of the product composts.

The proper functioning of the composting process requires a correlation between physicochemical parameters of the process and the parameters that define the quality of the products composts. The compost quality is a function of the fertilizer content, of the contents of trace metal elements (TME) and the analysis of maturation of the product compost.

\section{Chemical elements}

The results of analyzes of the chemical elements and the $\mathrm{C} / \mathrm{N}$ ratio are consistent with international standards (Table 5).

\begin{tabular}{|c|c|c|c|c|c|c|c|c|c|c|c|c|}
\hline Compost & C1/10 & C1/40 & C2/10 & C2/40 & C3/10 & C3/40 & C4/10 & C4/40 & $\begin{array}{l}\text { Compost Labé } \\
\text { * }\end{array}$ & $\begin{array}{l}\text { Compost } \\
* *\end{array}$ & $\begin{array}{l}\text { Compost } \\
* * *\end{array}$ & $\begin{array}{l}\text { Norm } \\
\text { NFU } \\
44051\end{array}$ \\
\hline $\mathrm{pH}$ (u.pH) & 8.4 & 8.5 & 9.2 & 9.2 & 8.9 & 9.1 & 8.68 & 9.2 & $8.2 / 8.8$ & 7.8 & 9.3 & - \\
\hline$\% \mathrm{MO}$ & 31.3 & 37.2 & 34.6 & 36.9 & 38.8 & 48.3 & 42.1 & 47.2 & $32 / 34$ & $35 / 40$ & 34 & $\begin{array}{l}\geq \quad 20 \% \\
M B\end{array}$ \\
\hline$\% \mathrm{C}$ & 15.1 & 18.6 & 17.3 & 17.95 & 19.4 & 24.15 & 21.0 & 23.6 & $16.2 / 13.8$ & $20.3 / 23.2$ & 19 & $\geq 10$ \\
\hline$\%$ N-NTK & 0.7 & 0.8 & 0.9 & 1.01 & 1.09 & 1.27 & 1.14 & 1.19 & $1.4 / 0.88$ & $1.0 / 2.0$ & 0.8 & $<3 \%$ \\
\hline $\mathrm{C} / \mathrm{N}$ & 21 & 22 & 19 & 17 & 18 & 19 & 18 & 19 & $11 / 16$ & $11.6 / 20.3$ & 24 & 16.2 \\
\hline
\end{tabular}

Table 5: Chemical characteristics of different composts.

The $\mathrm{pH}$ of the compost produced vary between 8 and 9, this alkalinity is related to the coupled predominance of ammoniacal nitrogen in mineral form $\left(\mathrm{NH}_{4+}\right)$ with the base cations $\left(\mathrm{Ca}^{2+}, \mathrm{Mg}^{2+}, \mathrm{K}\right.$ ${ }^{+}$and $\left.\mathrm{Na}^{+}\right)$) which are in composts (Theories Brønsted-Lowry, 1923). These results are in agreement with those of Pfeiffer [28] and those of Roletto et al. [29], Forster et al. [30], Avnimelech et al. [31] cited in Francou et al. [32]. According Avnimelech et al. [31], the ripe composts are characterized by of the $\mathrm{pH}$ of between 7 and 9 .

The $\mathrm{C} / \mathrm{N}$ ratios of the various composts remain high between 17 and 22 but, they are accordance to those found in the literature (Table 5).
The higher the $\mathrm{C} / \mathrm{N}$ ratio is high, the less nitrogen is quickly available. These results show that the nitrogen is in organic form, indicating that the different composts are from good amendments organics [33]. The value of $\mathrm{C} / \mathrm{N}$ is inadequate to determine the maturity of compost [34-37].

\section{Fertilizing elements}

The rates of the fertilizing elements are related to the nature of the MSW [26]. Assay results of these elements show that composts contain high rates of $\mathrm{P}, \mathrm{K}, \mathrm{Na}, \mathrm{Mg}$ and $\mathrm{Ca}$ (Table 6). 
Citation: Naïmaa T, Guyb M, Sergeb C (2016) Sorting-Composting of Biodegradable Waste in the Municipality of Chief (Algeria): The Key Steps. Int J Waste Resour 6: 204. doi:10.4172/2252-5211.1000204

Page 9 of 11

\begin{tabular}{|c|c|c|c|c|c|}
\hline Compost & $\mathrm{mgP2O} / \mathrm{kg}$ & mgK20/kg & $\mathrm{mgNa} 2 \mathrm{O} / \mathrm{kg}$ & $\mathrm{mgMgO} / \mathrm{kg}$ & $\mathrm{mgCaO} / \mathrm{kg}$ \\
\hline $\mathrm{C} 1 / 10$ & 8608 & 9640 & 7661 & 4002 & 15273 \\
\hline $\mathrm{C} 1 / 40$ & 9732 & 9510 & 7472 & 4290 & 12470 \\
\hline $\mathrm{C} 2 / 10$ & 13507 & 7323 & 8816 & 5005 & 19520 \\
\hline $\mathrm{C} 2 / 40$ & 15506 & 6856 & 9146 & 4722 & 13876 \\
\hline $\mathrm{C} 3 / 10$ & 3954 & 8966 & 7260 & 5012 & 27123 \\
\hline $\mathrm{C} 3 / 40$ & 5390 & 8276 & 6966 & 4630 & 25190 \\
\hline $\mathrm{C} 4 / 10$ & 8597 & 8173 & 6639 & 5573 & 16310 \\
\hline $\mathrm{C} 4 / 40$ & 9636 & 7466 & 6396 & 5131 & 13560 \\
\hline Benin(1) (1999) & 45800 & 6200 & - & 3600 & 54600 \\
\hline Guinée(2) (2001) & 10500 & 10900 & - & 7500 & 57500 \\
\hline Mali(3) (2003) & 9200 & 10600 & - & 4600 & 90000 \\
\hline Togo(4) (2011) & 13600 & 17300 & - & 2800 & 16200 \\
\hline
\end{tabular}

Table 6: Composition of the compost in fertilizing elements (/ DM).

The results are in agreement with those obtained by N'Dayegamlye [38], in Canada. Phosphorus levels are comparable to those from Compaoré [1], in Burkina Faso, and to those determined by fertilizing elements in Ouagadougou. These agronomic qualities are comparable to those of Rytz, Mbuligwe et al., Matejka et al., Soumaré et al., Charny and Koledzi [2,27,37,39-41]. The composts obtained are rich in elements minerals $(\mathrm{N}, \mathrm{P}$, and $\mathrm{K})$ and trace elements $(\mathrm{Ca}, \mathrm{Mg}$ and $\mathrm{Na})$. These elements can be bringing by the putrescible [41]. Their fertilizing character allows them to act as the chemical fertilizers, by enriching the soil in N, P and K. They are also used as organic amendments; they act on the stability physical, chemical and biological soil [42].

\section{Elements trace metallic (ETM)}

In this study, analyzes of the elements metal trace were oriented on 4 elements considered metal pollution indicators. The results show that the concentrations in $\mathrm{Cd}, \mathrm{Cu}, \mathrm{Ni}$ and $\mathrm{Zn}$ are less than the limits recommended by the NFU 44051 French standard. But, it must be mentioned that in composts $\mathrm{C}_{2}, \mathrm{C}_{3}$ and $\mathrm{C}_{4}$ (coarse and fine), the $\mathrm{Pb}$ content exceeds the permissible standard ( $180 \mathrm{mg} / \mathrm{kg}$ compost) (Table 7). This element can come from the atmosphere (petrol with $\mathrm{Pb}$ ) and of the papers and cardboards (the printing inks with $\mathrm{Pb}$ ). But, according to the work of Koledzi [2], the retention from Plumb is high when the rate of organic matter is high. In the composts $\mathrm{C}_{2}, \mathrm{C}_{3}$ and $\mathrm{C}_{4}$, the organic matter content varies between $34 \%$ and $48 \%$, of the rates enough high compared to the standard. Therefore, the bulk of the $\mathrm{Pb}$ content will be fixed by the organic material, which gives a low mobility of the element in the soil. Indeed, the elements traces metallic are converted into chemical forms not reactive and unavailable to plants [5].

\begin{tabular}{|l|l|l|l|l|l|l|l|l|l|}
\hline Composts & $\mathbf{C 1 / 1 0}$ & $\mathbf{C 1 / 4 0}$ & $\mathbf{C 2 / 1 0}$ & $\mathbf{C 2 / 4 0}$ & $\mathbf{C 3 / 1 0}$ & $\mathbf{C ~ 3 / 4 0}$ & $\mathbf{C 4 / 1 0}$ & $\mathbf{C 4 / 1 0}$ & $\begin{array}{l}\text { Norm NFU } \\
\mathbf{4 4} \mathbf{0 5 1}\end{array}$ \\
\hline $\begin{array}{l}\text { ETM } \\
(\mathrm{mg} / \mathrm{kg} / \mathrm{DM})\end{array}$ & & & & & & & & \\
\hline $\mathrm{Cd}$ & 2.5 & 2.2 & 2.5 & 2.2 & 2.3 & 2.2 & 2.5 & 2.6 & 3 \\
\hline $\mathrm{Cu}$ & 113.4 & 102.1 & 83.2 & 88 & 72.2 & 49.6 & 78.3 & 107.7 & 300 \\
\hline $\mathrm{Pb}$ & 119.4 & 150.5 & 258.4 & 356.7 & 196.7 & 289.1 & 225.3 & 179.3 & 180 \\
\hline $\mathrm{Ni}$ & 15.7 & 29.0 & 17.5 & 16.4 & 34.8 & 30.5 & 37.7 & 42.7 & 60 \\
\hline $\mathrm{Zn}$ & 477.2 & 398.2 & 370.5 & 496.9 & 247.2 & 224.9 & 315.8 & 262.9 & 600 \\
\hline
\end{tabular}

Table 7: The mean values of the contents in the elements trace metallic. 


\section{Toxicity testing}

The Toxicity tests are an essential criterion to consider in assessing the quality and the maturity of compost in relation to its use as an organic amendment in agriculture. Indeed, phytotoxicity tests are the only way to assess toxic effects of immature compost. The phytotoxicity effect of immature compost is due to the ammonia emission, and to the presence of organic acids [43-45]. The ethylene oxide which originates from the decomposition of immature compost oxide has a phytotoxic effect on the plants [46].

\section{Germination Index, GI (Zucconi et al. [15])}

The significant germination indices are obtained with the $25 \%$ dose and $50 \%$ compost extract for the different composts (Table 8 ).

\begin{tabular}{|c|c|c|c|c|c|}
\hline Doses & $100 \%$ DW & $75 \% \mathrm{DW}+25 \% \mathrm{CE}$ & $50 \% \mathrm{DW}+50 \% \mathrm{CE}$ & $25 \%$ DW $+75 \% \mathrm{CE}$ & $100 \% \mathrm{CE}$ \\
\hline \multicolumn{6}{|l|}{$\mathrm{C} 1$} \\
\hline Cress & 100 & 65 & 58 & 54 & 49 \\
\hline lettuce & 100 & 93 & 92 & 62 & 48 \\
\hline \multicolumn{6}{|l|}{$\mathrm{C} 2$} \\
\hline Cress & 100 & 85 & 85 & 58 & 47 \\
\hline lettuce & 100 & 77 & 67 & 61 & 46 \\
\hline \multicolumn{6}{|l|}{ C3 } \\
\hline Cress & 100 & 77 & 74 & 67 & 46 \\
\hline lettuce & 100 & 58 & 64 & 61 & 42 \\
\hline \multicolumn{6}{|l|}{$\mathrm{C} 4$} \\
\hline Cress & 100 & 92 & 72 & 64 & 52 \\
\hline lettuce & 100 & 87 & 75 & 67 & 54 \\
\hline
\end{tabular}

Table 8: The rate of germination indices watercress seeds and of the lettuce seeds. DW: Distilled Water; CE: Compost Extract.

According Zucconi et al. [15], compost is considered non-toxic when its germination index is exceeds $50 \%$. A dose of $75 \%$ compost extract gives of the germination indices rate from $54 \%$ to $67 \%$ with the cress seeds. The same dose gives for germination index rates between $61 \%$ and $67 \%$ with the lettuce seeds. The pure compost extract $(100 \%$ CE) gave percentages between $46 \%$ and $52 \%$. The same dose gives of the rate between $42 \%$ and $54 \%$ with the seeds of lettuce. The rates of the most significant germination index were obtained with doses of $25 \%$ and $50 \%$ extract compost for both cultures. These results show that the germination index varies with of extracts compost doses and the type of culture.

\section{Conclusion}

This experiment is a validation of the assumptions obtained from the results of physic-chemical characterization of MSW of the municipality of Chlef. The wastes contain more than $70 \%$ intended for composting. This study allowed comparing four types of composting process (different substrates and different frequencies of the upturns).

The parameters physicochemical and biological indicate that the composts, at the end of the process have a $\mathrm{pH}$ between 7 and 9 , the $\mathrm{C} / \mathrm{N}$ ratios relatively high between 17 and 22 , the $\mathrm{Pb}$ rate which is above the standard but, they can be retained by the organic matter in the soil. It is urgent to establish a more suitable sorting that will reduce the rates of elements trace metallic of product composts. The composts do not exhibit phytotoxicity. They contain nutrients that can enable them to act as fertilizers. Mass balances show that the resulting compost rates exceed $50 \%$ of the raw material. This treatment process constitutes a production pathway from amendments organic. And it allows an improvement of the physic-chemicals properties and biological of soil and therefore, the yield and quality of crops $[47,48]$.

Finally, these results show that the techniques used can be successfully applied for valuation by composting of the part fermentable.

\section{References}

1. Compaoré E, Nanéma LS (2010) "Composting and the quality of compost of the municipal solid waste of city of Bobo-Dioulasso, Burkina Faso". Tropicultura, 28: 232-237.

2. Koledzi E, Baba G, Feuillade G, et Matejka G (2011) Physical characterization of solid urban waste in Lome, Togo, from the perspective of decentralized composting in neighborhoods. Francophone Revue of Industrial Ecology pp. 8-9.

3. Kjeldsen P, Barlaz MA, Rooker AP, Baun A, Ledin A et al. (2002) "Present and long-term composition of MSW landfill leachate: A review". Environ Sci Technol 32: 297-336.

4. Francou C (2003) Stabilization of organic matter during composting: Influence of the nature of the waste and process of composting - Research of indicators relevant. Thesis presented to obtain the degree of Doctor of the Institut National Agronomique Paris Grignon.

5. Mustin M (1987) Compost, the organic matter management. Dubuse, Paris.

6. Hue NV, Ikwa H, Silva JA (1994) Increasing plant-available phosphorus in an ultimo with yard-waste compost. Commun Soil Sci Plant Annal 25: 3291-3303. 
7. Sims JT (1990) Nitrogen mineralization and elemental availability in soils amended with composted sewage sludge. J Environ Qual 19: 669-675.

8. Unmar G, Mohee R (2008) Assessing the effect of biodegradable and degradable plastics on the composting of green wastes and compost quality. Bioresour Technol 99: 6738-6744.

9. Giroux M, et Audesse P (2004) Comparison of two methods for determining organic carbon, total nitrogen and $\mathrm{C} / \mathrm{N}$ ratio of various organic amendments and manure. Agrosol 15: 107-110.

10. Barrena R, Turet J, Busquets A, Farrés M, Font X, et al. (2011) Respirometric screening of several types of manure and mixtures intended for composting. Bioresour Technol 102: 1367-1377.

11. Adouby K, Akissi WLCK, Yao B (2007) Removal of heavy metal ions $(\mathrm{Pb} 2+, \mathrm{Cu} 2+)$ in aqueous solutions by pterygota macrocarpa sawdust. J Applied Sci 7: 1864-1872.

12. Bustamante MA, Paresed C, Marhuenda-Egea FC, Perez-Espinosa A, Bernal MP, et al. (2008) Co- composting of distillery wastes with animal manures: Carbon and nitrogen transformations in the evaluation of compost stability. Chemosphere 72: 551-557.

13. Belyaeva ON, Haynes R (2009) Chemical, microbial and physical properties of manufactured soils produced by co-composting municipal green waste with coal fly ash. Bioresour Technol 100: 5203-5209.

14. Koffi LCK, Adouby EN, Wandan BY, Kotchi KP (2010) Sorption and desorpotion of $\mathrm{Pb}$ (II) from aqueous solution using Triplochiton scleroxylon sawdust as sorbent. J Applied Sci 10: 1536-1544.

15. Zucconi F, Pera A, Forte M, et de Bertoldi M (1981) "Evaluating toxicity of immature compost". Biocycle 22: 54-57.

16. Kaiser M (1983) Analysis of microbiology of compost. Part 1 Compost information 12: 9-13.

17. Barrigton S, Choinière D, Trigui M, Knight W (2003) Compost convective airflow under passive aeration. Bioresour Technol 86: 259-266.

18. Mustin M (1997) Compost, the organic matter management. Dubusc, Paris.

19. McKinley VL, Vestal JR (1984) Biokinetic analyses of adaptation and succession: microbial activity in composting municipal sewage sludge. Appl Environ Microbiol 47: 933-941.

20. Bernal MP, Paredes C, Sanchez-Monedero MA, Cegarra J (1998) Maturity and stability parameters of composts prepared with a wide range of organic wastes. Bioresour Technol 63: 91-99.

21. Laos F, Mazzarino MJ, Walter I, Roselli L, Satti P, et al. (2002) Composting of fish offal and biosolids in northwestern Patagonia Bioresour Technol 81: 179-186.

22. Grigatti M, Ciavatta C, Gessa C (2004) Evolution of organic matter from sewage sludge and garden trimming during composting. Bioresour Technol 91: 163-169.

23. Godden B (1986) Study of the composting process of cattle manure. PhD in Agricultural Sciences, Free University of Brussels. Microbiology Laboratory, 136 pages + annexes.

24. Leclerc B (2001) Guide des matières organiques. Deuxième édition, Tome I. ITAB - Paris.

25. Jeris JS, Regan RW (1973) Controlling environmental parameters for optimum composting. Compost Sci 14: 10-23.

26. Saoudi B (2001) "Composting household waste and recycling compost: Case of small and medium towns in Morocco", edition Acts, 104.

27. Matejka G, De LasHeras F, Klein A, Paqueteau F, Barbier J, et al. (2001) Composting of municipal solid waste in Labé (Guinea): Process optimisation and agronomic development. Eight International Waste Management and Landfill Symposium. Cagliari, Italy.

28. Pfeiffer E (1979) The fecundity of the earth. (7thedn), Triads, Florida.

29. Roletto ER, Chiono, Barberis E (1985b) "Investigation on humic matter from de composing poplar bark". Agricultural Wastes 12: 261-272.
30. Forster JC, Zech W, Wurdinger E (1993) Comparison of chemical and microbial methods for the characterization of the maturity of composts from contrasting sources. Biol Fertil Soils 16: 93-99.

31. Avnimelech Y, Bruner M, Ezrony I, Sela R, Kochba M (1996) Stability indexes for municipal solid waste compost. Compost Sci Util 4: 13-20.

32. Francou C, Poitrenaud M, Houot S (2005) Stabilization of organic matter during Composting: Influence of Process and Feedstocks. Compost Sci Util 13: 72-83.

33. Équiterre (2009) Organic amendments: manures and composts.

34. Morel JL, Guckert A, Nicolardot B, Benistant D, Catroux G, et al. (1986) Study of the evolution of physicochemical characteristics and the biological stability of household waste during composting. Agronomy 8: 693-701

35. Saviozzi A, Levi-Minzi R, Riffaldi R (1988) "Maturity evaluation of organic waste". BioCycle 29: 54-56.

36. Wittling-Serra C (1995) Valorization of the composts of household waste in crop protection: Influence of the composts intake on the development of telluric diseases and pesticide behavior in soil. Memory of thesis for obtaining the degree of doctor The INA-PG 220.

37. Soumaré M, Tack FM, Verloo MG (2003) Characterisation of Malian and Belgian solid waste composts with respect to fertility and suitability for land application. Waste Manag 23: 517-522.

38. N'Dayegamlye A, Drapeau A, Laverdière MR (2005) Effect of intakes of the household waste composts on yields of crops certain soil properties. Research Institute of the Agri-Environment department. Agrosol pp. $142-143$

39. Rytz I (2001) Assessment of a decentralised composting scheme in Dhaka, Bangladesh - technical, operational, organisational and financial aspects. Eawag/Sandec and Waste Concern, Zurich, Switzerland.

40. Mbuligwe SE, Kassenga GR, Kaseva ME, Chaggu EJ (2002) Potential and constraints of composting domestic's solid waste in developing countries: findings from a pilot study in Dar es Salaam. Resour Conserv Recy 36: 45-59.

41. Charnay F (2005) Composting of waste in developing countries: Elaboration of a methodological approach for a sustainable production of compost. University of Limoges.

42. Bertoldi M, DeVallini G, Pera A (1983) The biology of composting: a review. Waste Manage Res 1: 157-176.

43. Tang JC, Maie N, Tada Y, Katayama A (2006) Characterizations of the maturing process of cattle manure compost. Process Biochemistry 41: 380-389.

44. Manios VI, Tsikalas PE, Siminis HI (1989) Phytotoxicity of olive tree leaf compost in relation to the organic acid concentration. Biol Waste 27: 307-317.

45. Alburquerque JA, Gonzalvez J, Garcia D, Ce garra J (2006) Measuring detoxification and maturity in compost made from "alperujo", the solid by-product of extracting olive oil by the two-phase centrifugation system. Chemosphere 64: 470-477.

46. Wong MH (1985) Phytotoxicity of refuse compost during the process of maturation. Environ Pollut A 37: 159-174.

47. Barrington $\mathrm{S}$, Choinière D, Trigui M, Knight W (2002) Effect of carbon source on compost nitrogen and carbon losses. Bioresour Technol 83: 189-194.

48. Koledzi E (2010) Valuation of urban waste: Implementation of the decentralized composting in the Lomé neighborhood; Methods and Perspectives. Doctoral thesis under joint supervision of Lome, University of Limoges. 